\title{
Social utility of small-scale art festivals with creative tourism in Portugal
}

Fiona Eva Bakas, Postdoctoral Researcher at Centre for Social Studies, University of Coimbra, Portugal and member of Cities, Culture and Architecture (CCARQ).

Nancy Duxbury, Integrated Researcher at Centre for Social Studies, University of Coimbra, Portugal and member of Cities, Culture and Architecture (CCARQ).

Paula Remoaldo, Professor of Geography at University of Minho, Portugal and member of Heritage and Territory Laboratory (Lab2PT).

Olga Matos, Associate Professor at Polytechnic of Viana do Castelo, Portugal and member of Landscapes, Heritage and Territory Laboratory (Lab2PT).

Keywords: small-scale festivals, art, creative tourism, social capital, shared meaning, strategic planning

\section{Abstract}

Purpose of this paper: This article aims to address the gaps in research on strategic planning for social impacts of small-scale events in rural areas and small cities. This is achieved by investigating the social utility inferred by small-scale art festivals with a creative tourism element in terms of increasing social capital and positive social change, from an event stakeholder perspective.

Design/methodology/approach: The identified gap in knowledge is addressed by using interviews and fieldnotes from participant observation to co-create meaning with the organizers of four small-scale art festivals in small cities and rural areas in Portugal. Theoretical frameworks relating to creative tourism development and social capital creation are used to analyze the social utility of small-scale art festivals.

Findings: Creative tourism activities are integrated within small-scale art festivals in small cities and rural areas in various ways, mainly through art-related workshops. Significant empirical data give insight into how small-scale art festivals create social value by increasing the host community's pride and reinforcing the social fabric of the festival's 'portable' community, in part through these creative tourism activities.

Research limitations/implications: One of the limitations of this study is that it focuses on the perspectives and insights of the festival organizers. An analysis of the festival participants' views, local community stakeholder analysis, and community impact analyses would offer further insights into how the creative tourism experiences and other moments of shared meaning generation within small-scale art festivals influence the creation of social utility.

What is original/value of paper: This paper offers insights into how creative tourism activities are being integrated into small-scale art festivals within small cities and rural contexts, and how these events are generating social utility for their communities. This addresses significant gaps in the literature on strategic planning for social impacts of events, particularly in the context of small-scale events in rural areas/small cities. 


\section{Introduction}

Festivals, defined as "the celebration of a specific theme to which the public is invited for a limited period of time" (Grappi and Montanari, 2011, p. 1129) are one of the fastest growing types of events, and have increased in number, diversity, and popularity since the 1980s (Akhoondnejad, 2016). Festivals can be seen as a strategy to achieve economic development, a means to enhance the life of local people, and a way to reinforce social cohesion within communities (Lee, 2014). A festival can provide a "symbolic social space wherein event participants instantiate a shared and valued sense of community" (Ziakas and Costa, 2012, p. 28 ) with a host community's practical and existential issues shaping the meaning that an event conveys. Festivals allow for the creation of tighter social networks and connectedness of local populations, especially within the context of small-scale events (Taks, Chalip, and Green, 2015).

While there has been considerable research on the economic impacts of events, with recent research showing that small-scale events require fewer resources and are therefore more likely to generate more positive economic outcomes than mega-events (Agha and Taks, 2015), less has been written on how festivals operate as a mechanism to build and sustain social capital within a community. Festivals can achieve this by providing occasions when communities reify their group identity and also when members can signal their commitment to the common good (Rao, 2001). Social capital can be generated in festivals when reinforcing ties within the community, whether by creating common knowledge, building trust, or facilitating the formation of networks and increasing social cohesion (Coleman, 1988). The concept of 'social utility", defined as "the accumulated social value an event derives as a result of implementing strategies to attain and magnify social capital, community capacity and positive social change" (Ziakas, 2016, p. 1137), is instrumental in understanding the key dynamics associated with planning and implementing small-scale festivals.

A lack of research specifically investigates the social consequences of events within rural communities (Reid, 2007). Furthermore, there is a need to consider 'the countryside' or the 'rural' as a place where the creative economy is differently manifested and articulated from the now standard 'creative script' based on cities (Bell and Jayne, 2010). In rural areas, community members may view the festival not only as a money-making tourist attraction, but also (and perhaps primarily) as an enjoyable community-based event that boosts community pride and where they participate as either host or visitor, or both (De Bres and Davis, 2001). In a rural and small cities context, small-scale festivals can be significant events as they have the potential to periodically renew a community, demonstrate the value of local institutions to the local population, and provide a platform for community involvement and cultural development (Jepson and Clarke, 2013).

While some research has been conducted on how festivals link to tourism in an urban context (Newbold, Maughan, Jordan, and Bianchini, 2015), more limited research on this link exists for rural contexts (Gibson and Connell, 2011; Stevenson, 2016). Within the context of creative tourism, which can connect artisans in rural areas with tourism (Bakas, Duxbury, and Castro, 2018), small-scale local festivals can create both a context and a link between the local community and visitors. In particular, the organization of workshops (e.g., in theatre, dance, comedy, or visual arts) and other occasions to learn how local products are made can give shape to and fortify these links. 
Creative tourism is a tourist activity that incorporates four dimensions: active participation, creative self-expression, connection to place, and community engagement (Bakas and Duxbury, 2018). 'CREATOUR: Creative Tourism Destination Development in Small Cities and Rural Areas' (2016-2019) is a 3-year research and application project in Portugal that aligns with rural development goals of reviving and sustaining local crafts and traditions and providing a meaningful platform for visitors to engage with the local community. Since this is a new type of tourism, there are few studies investigating how creative tourism activities can reach potential clients, especially within rural areas, which are often time-consuming and expensive for travellers to reach (Duxbury and Richards, 2019). This context raises the question of what circumstances and arrangements allow for the favourable accommodation of creative tourism activities within small-scale art festivals, and how these settings may stimulate social utility by promoting various engagements between visitors/tourists and local community residents. This study focuses on four small-scale festivals located in the central (Centro) and northern (Norte) regions of Portugal that are participants in the CREATOUR project. Since these processes are the outcomes of active strategic planning by small-scale festival organizers, interviewing the people designing and managing these processes is viewed as central to understanding the strategic construction of environments that foster suitable and amenable dynamics (De Bres and Davis, 2001).

This article begins with a contextualization of these small-scale art festivals in terms of the changing Portuguese 'rural' and its intersection with creative tourism. It then examines events tourism research on small-scale, locally organized festivals, and on the social utility of festivals. The methodology of the current study is outlined, and the results and analysis are presented according to two key themes that emerged in the study: small-scale art festivals as fertile ground for the evolution of creative tourism activities; and the social utility of smallscale art festivals in the rural/small cities Portuguese context. The article concludes with an overview of research findings and suggestions for addressing the limitations of the current study in future research.

\section{The 'rural' and creative tourism}

In rural communities, the arts and creative industries are strategic sectors in regional revitalization because they can stimulate community cohesion and also provide tourism-based opportunities (Duxbury, Campbell, and Keurvorst, 2011). The 'rural idyll' attracts tourists to rural areas and engenders a 'value of remoteness' in which distance from urban obligations creates an environment for 'de-stressing' as well as a creative freedom to experiment (Matarasso, 2004, p. 25). Rural areas are increasingly associated with both 'escape' and 'renewal', fuelling the development, for example, of 'digital detox' camps (e.g., http://digitaldetox.org) and 'mindful travel' strategies popular among travelers from (at least) Europe and North America (Chen, Scott, and Benckendorff, 2017; Currie, 2005).

In recent decades, rural areas in southern Europe have experienced the waning importance of agriculture to their general economy, the decline of farming populations, a reduction of incomes, greater structural complexity of employment, and the effects of transformations associated with the European Union's Common Agricultural Policy (Verinis, 2011). In Portugal, a threefold narrative on the rural has emerged in lay discourses: (1) a 'pre-modernity' discourse, in which rural areas are generally portrayed as less developed and in need of change; (2) a productivist perspective, which associates the rural with agricultural modernization; and

(3) a 'rural renaissance' vision, in which the countryside is understood as a repository of 
traditional cultural values and as in need of preservation (da Silva, Figueiredo, Eusébio, and Carneiro, 2016). Accompanying this third narrative, we observe the emergence of a countryside whose economic foundation has shifted from agricultural production to become a site of consumption, tourism, and recreation. However, the touristic promotion of the countryside is often based on 'global' images rather than in local features, which tends to induce a process of 'McRuralisation' (Figueiredo, 2013). In recent years, small-scale festivals in European rural areas have been increasingly leveraged as an economic tool, stimulating short-term employment, improving the skills and capacity of residents to find work and to reinvent place images, particularly in view of changing demographics and declining industries (Ortiz, 2017). While most rural festivals are modest, socially motivated, and not especially geared to tourism, they are significant because they provide a platform for community involvement and cultural development and because of their sheer quantity and geographical ubiquity (Gibson and Connell, 2016).

Tourism has often been seen as a destructive force for local crafts and traditions because of the perceived alterations in local traditions that occur through their touristification. In light of these concerns, creative tourism is a novel and active way of both preserving and extending cultural heritage as creative tourism products are inspired by and built locally from the distinct endogenous resources of local places and people (CREATOUR, 2017; Remoaldo et al., 2019). Creative tourism is also fueled by the new paradigm of the twenty-first century according to which tourists strive to find 'transformative' experiences, focus on self-development, are more conscious of their actions, and want to be active participants in tourism experiences rather than passive observers (UNTWO, 2016). These people, labelled 'cultural creatives', now form about $35 \%$ of each European country's population, plus or minus 2\% (Anderson and Ray, 2015). Through creative tourism, visitors can "get under the skin" (Landry, 2010, p. 37) of a place as they engage in everyday activities of locals (and with locals), which comprise the new 'exotic'. Modern interpretations of creative tourism understand that tourist activities have the opportunity to co-create and co-preserve local traditions, while also providing participants opportunities to develop creative skills and engage with the local community (Duxbury, Silva, and Castro, 2019). The contemporary vision of creative tourism has an expanded focus on connections between travelers and residents, and places importance on rooting creative intangibles to the specific place in which activities occur (Blapp, 2015; OECD, 2014).

Since creative tourism is a relatively new field, limited research has been conducted to date on what makes a creative tourism activity successful and sustainable. Recent research into creative tourism development and presentation frameworks emerging in Portugal (Duxbury, Carvalho, Castro, Bakas, and Silva, 2018) found that creative tourism in rural areas is being brought to the public through five main frameworks:

- Local artisan/producer networks - developed by municipalities, development associations, and private initiatives;

- Small-scale art festivals;

- Accommodations+ (including artistic residencies);

- Thematic series of related events and workshops; and

- Stand-alone 'signature' activities.

Within this array of approaches, we are observing that small-scale art festivals can provide a critical mass of activity and marketing, which is required to attract creative tourists to rural areas for the duration of a few days. However, limited literature addresses the ways in which creative tourism activities are successfully integrated within small-scale art festivals and the resultant social impacts that result from this. 


\section{Festivals within events tourism}

While festivals are often hidden within the literature on cultural tourism with only limited attention in events tourism literature (McKercher and du Cros, 2002; Richards, 2007), the study of festival tourism is a growing area of interest (UNESCO, 2015) and various approaches are being taken to investigate it. Many studies focus on the economic analysis of festivals, aiming to estimate an aggregate measure of income and employment change attributable to the festival and then calculating local multiplier effects (Kostopoulou, Vagionis, and Kourkouridis, 2013). Other research has examined festivals as events in the context of place marketing, urban development, tourism, and social change (Picard and Robinson, 2006; Brito and Richards, 2017); their role in producing a direct and indirect sense of place (Lau, 2016); and tourist motivations to visit festivals (Kitterlin and Yoo, 2014), including the role of cultural identity and awareness of local traditions in attracting tourists to small-scale festivals (Stankova and Vassenska, 2015).

In recent years, festivals have been receiving increased attention from government entities and destinations because of anticipated benefits these festivals can bring to a locale and the lives of residents such as showcasing local cultural heritage; promoting the region, city, or town; attracting tourist revenues; and providing additional cultural entertainment offerings to local residents (Mair and Whitford, 2013). In their diversity, festivals engage both artists and visitors as active participants, providing a platform for a specific time-period for sharing cultural perceptions and expressions arising from history and tradition, cuisine and beverages, music and dancing. Recent research on festivals in Australia (Laing and Mair, 2015) shows that festivals can contribute to community engagement and social inclusion by increasing consumption, production, political engagement, and social interaction. Festivals can also help host communities create and promote a positive image of the host community in the minds of both residents and prospective visitors. However, research on the influence of festivals of residents' well-being shows no significant relationship between festivals and subjective wellbeing of residents (Yolal et al., 2016), opens up the question of how to strategically foster a festival's social impacts.

\subsection{Small-scale, locally organized festivals}

In small regional towns, a festival can be instrumental in mobilizing local cultural forces and resources, stimulating creative interventions, and planning activities that can affect local development and regeneration processes (O'Sullivan and Jackson, 2002). Empirical studies of small, local festivals within the tourism field all point to economic benefits, usually concerned with short-term impacts and direct, tangible outcomes such as adding jobs, hotel rooms, and business revenues (Felsenstein and Fleischer, 2003). Furthermore, tourism spin-offs deriving from the promotion of festivals are seen as one way of combating rural decline (Walmsey, 2003).

Much of the research and debate on the impact and roles played by small-scale festivals in regional development concentrates on their potential to attract tourists and therefore benefit the local economy (Comunian, 2015). Since smaller-scale festivals place a smaller strain on local community resources than mega-events, they are more likely to generate positive economic outcomes (Veltri, Miller, and Harris, 2009). The positive impacts of small-scale festivals extend far beyond income generation and can include strengthening the social fabric and identity of local communities and enriching the quality of life of small towns (Gibson and Connell, 2016). Non-mega sporting events, for example, have been shown to create tighter social networks and increase the connectedness of the local population, compared to mega- 
events (Taks, Chalip, and Green, 2015). Hosting small-scale events, which often means that locals get involved as volunteers in the event, contributes to quality of life and increased community spirit and pride (Gibson, Kaplanidou, and Kang, 2012). Small-scale festivals, as a leisure activity that fosters a festive sociability, can allow for the creation of social capital as they provide opportunities for social interaction, increasing social cohesion, encouraging the participation of specific social groups, and providing the potential for richer social ties (Glover and Hemingway, 2005).

Small-scale festivals in rural areas can also assist in the development or maintenance of community identity, an increasingly important element in community vitality and local sustainability. Although commonly rooted in local history, culture, and traditions, sometimes the community identity created by festivals is not based on these elements. For example, an Elvis revival festival (founded by an enthusiastic Elvis fan) in a small rural town west of Sydney, Australia, has successfully created an 'invented' tradition and place identity for the community (Brennan-Horley, Connell, and Gisbon, 2007) and many of the local residents where the Australian Elvis revival festival is held now identify within it, showing how community identities remain fluid, especially when influenced by the economic benefits (and conviviality) that festival tourism can provide. Tourist commodification of a festival can be condemned as a cultural misrepresentation, but it is significant to consider that by promoting a sense of pride, kinship, and community, even these festivals can lead to more positive identifications with the place and the local community.

\subsection{Social utility of festivals}

Festivals can renew the life-stream of a community and enhance both group and place identity (De Bres and Davis, 2001). The word 'community' can be used to describe a group of people who share identity, common interests, and shared beliefs or to describe a group of people unified by the geographical territory they occupy (Liepins, 2000). Past research had shown that festival organizers often focus on the "portable community" (Laing and Mair, 2015, p. 252), that is, the festival-goers, in their efforts to encourage social inclusion, but have more limited success in reaching out to local residents. Research on the participation of local residents in local festivals ranges from analyzing residents' involvement in the programming and planning decisions (e.g., Jepson and Clarke, 2013), to festivals as a training grounds for providing handson experience with logistics, hospitality, or human resource management, to the accessibility of the cultural event through free or nominal entry fees for local residents and particularly for lower socio-economic groups (Johnson, Currie, and Stanley, 2011).

The social dimension of culture, which emphasizes senses of identity, personal and collective expression, shared values, and social belonging provides additional angles through which to investigate how local festivals contribute to the social fabric of a community. Research has focused on the role of the festival space as a place for common participation in culture, for social expression of diverse opinions and perspectives, and for supporting social dialogue in an open space that over time becomes a community ritual. This social dimension of culture is emphasized in an examination of the dynamics of local cultural festivals in Strumica, Macedonia (Georgievska-Jakovleva and Pavlovski, 2015). It is also manifested in festivals in the rural United States, in which success is attributed to the festivals boosting the local community's pride of place (Waterman, 1998).

Social capital can be defined as the features of social life (networks, norms, and trust) that enable participants to pursue shared objectives. Social capital is the force that binds society together, transforming egocentric individuals into members of a community with shared 
interests and is linked to co-operation and reciprocity (Ziakas, 2016). Various types of social capital have been identified, for example, bridging social capital refers to links among people who are dissimilar, bonding social capital refers to links among people who are similar, and linking social capital refers to vertical connections with people in positions of authority (Vidal, 2004). Any institution that reinforces ties within a community, whether by generating common knowledge or by building trust by some other means, is building social capital by facilitating the formation of networks and increasing social cohesion (Rao, 2001).

While a link between social productivity and economic productivity exists, whereby villages with higher levels of social capital tending to have households with higher incomes (Narayan and Pritchett, 1999), limited research has been conducted on how social capital is built and sustained within a community. Festivals can create social wealth (and health) by promoting connectivity among diverse elements, such as the festival volunteers, locals, festival tourists, and artists, thus increasing these persons' collective social capital (Brennan-Horley, Connell, and Gisbon, 2007). Other elements of social wealth, such as trust and cooperation, can be nurtured through participation in cultural activities. Participation in local events is linked to the social development of community and creation of social capital as it encourages people to move beyond individualism, encouraging them instead to engage in social activities of shared meanings that will promote justice and cooperation, and to become more involved in the civic life of their community (Ferreira and Duxbury, 2017).

As "symbolic social space" (Ziakas, 2016, p. 1140) in events participants and audiences internalize shared meaning through projected event symbolisms and shared experiences. These shared meanings can facilitate a heightened sense of community and strengthen a community's social capital, and contextual dynamics can facilitate or inhibit the creation of shared meaning within an event. Host communities can strategically develop a performative social space aimed at contributing to social utility, countering social exclusion, and fostering community development (Ziakas and Costa, 2012). Within sports event literature, the creation of eventrelated social events that facilitate social opportunities and increase the feelings of being part of a community are increasingly being integrated into strategic planning of events (Chalip, 2006). Planning for events that have a high social utility and strategically optimizing the social outcomes of events is a novel suggested framework for planning events. Such an approach allows for a more holistic understanding of events in terms of the interactions occurring within a host community's social fabric that maintain or re-create the community's social order.

\section{Methodology}

This article's methodology incorporates an ontology that important knowledge lies in the ways in which the festival organizers perceive themselves and the festivals they manage, from which they act. The local, context-bound knowledge produced from this examination is nongeneralizable and does not purport to universal positivist claims of truth about festival organizers' conceptualizations of their roles. However, this research is of significance in furthering event tourism theorizing by providing a rich description of context-bound realities and the dynamics that occur within these situations. As social life is a result of interactions, qualitative research is used to make visible participants' knowledge, insights, and opinions and to interpret these in terms of the meaning they attach to them. Social life is dependent on conversations, and we are inspired by Lincoln and Guba's (1985) definition of an interview as a "conversation with a purpose" (p. 268). In order to investigate social change, in-depth conversations are necessary. The knowledge created in these conversational interviews is co- 
constructed between interviewer and interviewee as both persons bring together their interpretations of meaning and somewhere between what the participant says and what the interviewer understands knowledge is created from these interactions.

The empirical evidence for this study was gathered in 2017 and 2018 through in-person interviews held during on-site visits where ethnographic accounts of the festivals were also captured through fieldnotes and participant observation. Since festival organizers select the participating artists, set out themes, and provide other aspects of direction, they can be seen as knowledge 'gate-keepers' (Derrett, 2003) in this context. Hence, festival organizers were selected as the most appropriate people with whom to co-create knowledge for this article.

The in-person interviews that inform this study were held during each festival, at the festival location. They were recorded using a portable recording device and then transcribed. In total there were five semi-structured interviews. Three out of the four festival organizers were interviewed in Portuguese by native Portuguese speakers and the final one was interviewed in English by a native English speaker. The transcripts were then translated into English by a native English (and Portuguese) speaker. The interview guide consisted of six open-ended questions addressing the following topics: preparation of creative tourism activities, development of the activities, impacts on the community, how the activity went, the future sustainability of the project, and how the CREATOUR project could help to improve initiatives developed by festival organizers. Fieldnotes were recorded within a pre-prepared framework that had sections on logistics, activity development, creativity and culture, community impacts, and a general comments section. In total, five sets of fieldnotes were recorded.

Data from the fieldnotes and interviews were initially analyzed using open coding, according to which the researchers broke down the data into parts, looking for similarities and differences, and coded it using themes from the literature. A stage of focused coding then followed which involved the examination of reoccurring codes in the data and grouping them into larger overarching themes. Each of the four authors checked the themes and suggested changes, after which the final key themes discussed in this article emerged.

\subsection{Contextual parameters of the study: the small-scale local festivals studied}

The four small-scale festivals that were chosen as the investigative basis of this study are geographically situated in small cities or rural areas in the Norte and Centro regions of Portugal: EncontrArte Amares, Festival "L Burro i L Gueiteiro," Estival festival, and 180 Creative Camp. These festivals are part of the CREATOUR project, which involves five Portuguese research centres working with a range of cultural/creative organizations and other stakeholders located in small cities and rural areas across Portugal in the Norte, Centro, Alentejo, and Algarve regions. Each of the festivals are briefly described below, supplemented by a table showing relevant characteristics, including the creative tourism activities integrated within them.

\section{EncontrArte Amares, Municipality of Amares, Norte region}

The first edition of the EncontrArte Amares Festival was held in 2009 and it has a biennial periodicity. The festival aims to connect people with the arts through promoting artistic experimentation. EncontrArte Amares (Figure 1) has a multidisciplinary program (e.g., contemporary art exhibitions, artistic residences, and educational activities) and a lively dialogue between the radicalism of contemporary artistic expression and the traditional heritage of the Minho region. During the five days of EncontrArte Amares, an environment of 
experimentation, participation, conviviality, active contemplation, and freedom of thought is fostered. The festival also promotes the regions' immaterial heritage, highlighting local gastronomy, customs, images, sounds, stories, and know-how. Community involvement is high with about 130 residents working with the EncontrArte Amares team to develop artistic projects. These local participants included residents involved in local associations and enrolled in schools, who had the opportunity to work together with visiting creators in the artistic residences. From an operational perspective, local residents also provided some accommodations for the artists and worked on making bags and other materials that were incorporated in fabricating bedspreads with the impression a couple's photograph.

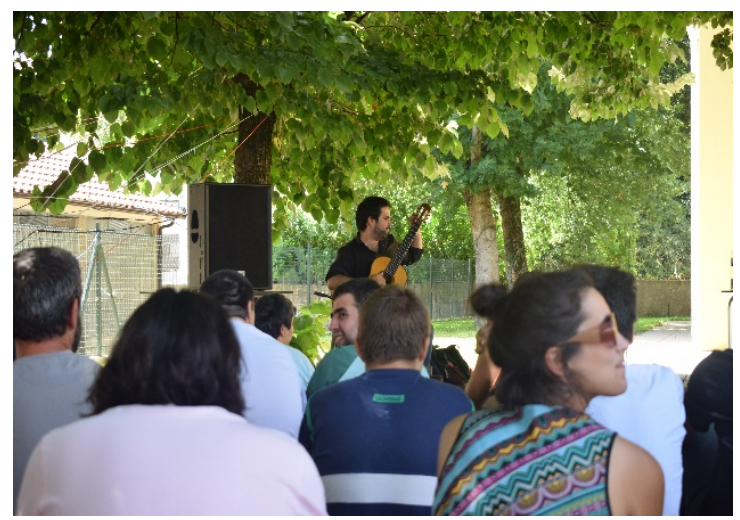

Figure 1. EncontrArte Amares festival performance (Photograph taken by Ricardo Gôja, Amares, 28 July 2017)

\section{Festival "L Burro i L Gueiteiro," Miranda do Douro, Norte region}

The Festival "L Burro i L Gueiteiro" is an annual itinerant festival that travels between three villages and is linked to the traditions of Miranda do Douro subregion (Figure 2). Occuring at the end of July each year, about 450 people participate in this festival, including artists and volunteers. Local community involvement is mainly in the form of participating in the operational organization of the event (i.e., as cooks, cleaners, security, logistics coordinators, etc.) and as musicians who play during the inter-village donkey walks. Local residents also provide the spaces where the workshops take place. Most participants reside in large tents and comprise a variety of ages, from teenagers to retirees. Focused around the breed of traditional donkeys of Miranda, this alternative traditional festival serves as a way of preserving this breed as well as preserving local culture. Workshops within the festival focus on traditional music and dances of the region and on playing traditional instruments, in particular, the bagpipe. The travelling festival takes place in several parishes of the county, moving all the logistics, staff, and activities from village to village, accompanied by donkeys, which are the main attraction of this itinerancy.

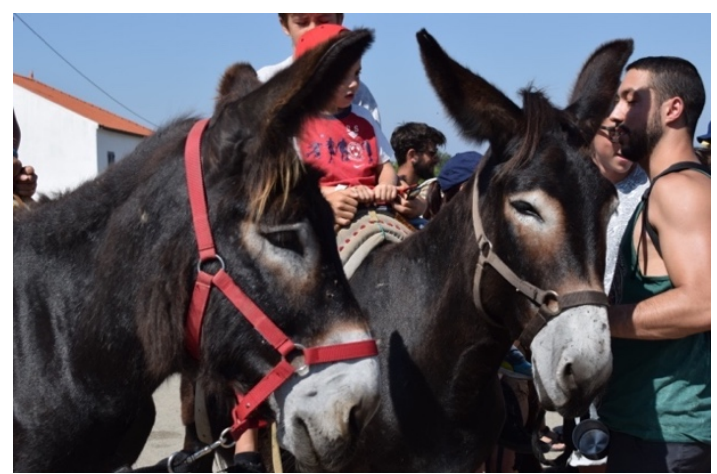

Figure 2. Participants and donkeys at the festival "L Burro i L Gueiteiro." (Photograph taken by Juliana Alves, Miranda do Douro, 28 July 2018) 


\section{Estival festival, Vale de Mondego, Guarda, Centro region}

Estival is an annual art festival held in a farm owned by a Dutch couple and operated by the FAIA Collective, a cooperative of young entrepreneurs educated in philosophy, psychology, biodynamic agriculture, ecology, and gastronomy. About 80 people participate in this annual week-long festival, including artists and volunteers. The majority of participants are Dutch and range in age from teenagers to retirees. Participants engage in workshops such as theatre, standup comedy, singing, dancing, wood sculpture (Figure 3), felting, mosaic-making, and graphic design/animation, and most stay in large tents. Each evening there are artistic performances, many created within the workshops (e.g., a theatrical performance), and on one evening everyone goes to the closest village to eat and dance with the local residents. Local residents are involved in cooking for this one night-time event, a village celebration where local residents and festival-participants meet to eat and dance. The village female-only choir performs at the festival, singing traditional Portuguese songs.

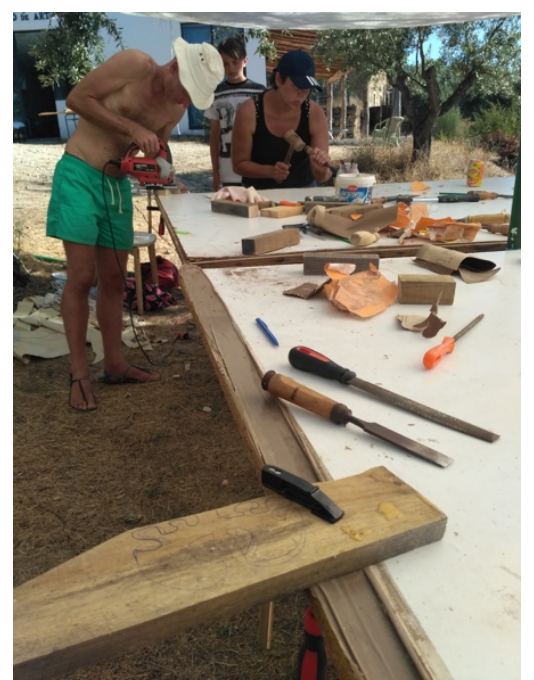

Figure 3. Wood sculpture workshop at Estival festival. (Photograph taken by Fiona Bakas, Faia, 8 August 2018)

\section{Creative Camp festival, Municipality of Abrantes, Centro region}

The 180 Creative Camp is an 8-day creative boot-camp that occurs in Abrantes, Portugal, on the first week of July each year. Its first edition was in 2013 and since then it has evolved into what is now a triplex concept: academy, featuring a series of workshops, conferences, and projects developed; factory, involving public interventions (Figure 4) and content productions with the local community; and festival, presenting concerts, live cinema, exhibitions, and public activities. The event attracts and hosts young 'creatives', most between 18 to 35 years old, from all over the world. The 180 Creative Camp provides time and space for these young creators and invited artists from a wide variety of disciplines (such as design, architecture, art, music, video, photography, illustration, and installation) to learn from each other, exchange experiences, and create together. Community involvement is found in the form of 160 children from a local school vacation program participating in several workshops, including an animal mask-making workshop; performances by the Abrantes Musicians Academy at a major music event during the Camp; and a local association providing transport services for festival participants. 


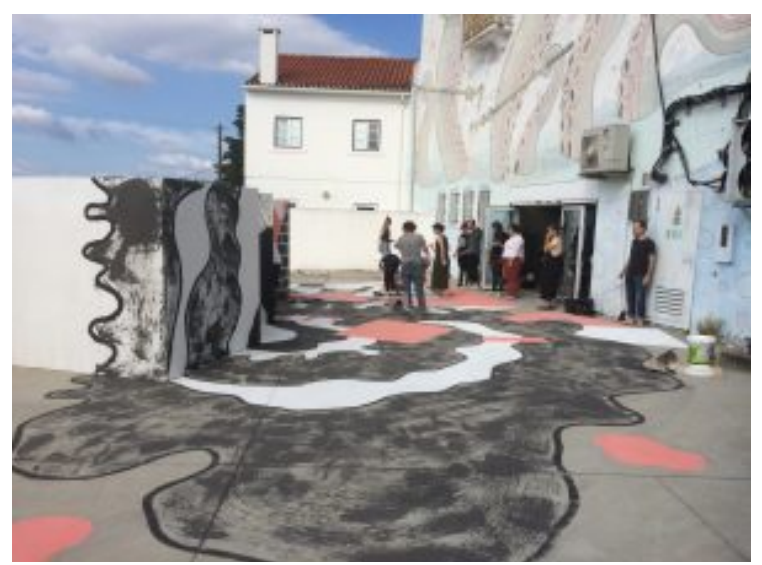

Figure 4. Artistic intervention by festival participants in Abrantes. (Photograph taken by Tiago Vinagre de Castro, Abrantes, 4 July 2018)

Table 1. Summary table of small-scale festivals participating in this study

\begin{tabular}{|c|c|c|c|c|c|}
\hline $\begin{array}{l}\text { Festival } \\
\text { name }\end{array}$ & $\begin{array}{l}\begin{array}{l}\text { Year } \\
\text { founded }\end{array} \\
\text { Frequency } \\
\text { Duration }\end{array}$ & Venue type & $\begin{array}{l}\text { Benefits to } \\
\text { local residents }\end{array}$ & $\begin{array}{l}\text { Number of } \\
\text { participants }\end{array}$ & $\begin{array}{l}\text { Creative tourism activities that } \\
\text { form part of the art festival }\end{array}$ \\
\hline EncontrArte & $\begin{array}{l}2009 \\
\text { Biennale } \\
5 \text { days }\end{array}$ & $\begin{array}{l}\text { Small city } \\
\text { Activities take } \\
\text { place around } \\
\text { the city }\end{array}$ & $\begin{array}{l}\text { Free entrance to } \\
\text { local residents }\end{array}$ & 950 & $\begin{array}{l}\text { Open rehearsals (e.g., folklore } \\
\text { group), guided visits to set up the } \\
\text { exhibitions of the festival, } \\
\text { activities in the artistic residences, } \\
\text { workshops/activities of painting, } \\
\text { sculpture, gastronomy, clay } \\
\text { modelling workshops, and } \\
\text { Cyanotype printing workshop. }\end{array}$ \\
\hline $\begin{array}{l}\text { L Burro i L } \\
\text { Gueiteiro }\end{array}$ & $\begin{array}{l}2002 \\
\text { Annual } \\
5 \text { days }\end{array}$ & $\begin{array}{l}\text { Rural and } \\
\text { remote } \\
\text { Moves from } \\
\text { village to } \\
\text { village every } \\
\text { day }\end{array}$ & $\begin{array}{l}\text { Discounted } \\
\text { entrance prices } \\
\text { for local } \\
\text { residents }\end{array}$ & $\begin{array}{l}450+40 \\
\text { volunteers }\end{array}$ & $\begin{array}{l}\text { Percussion workshops; dance } \\
\text { workshop of Miranda region } \\
\text { dances, e.g., dance of the } \\
\text { Pauliteiros de Miranda; } \\
\text { workshops in folk and electronic } \\
\text { music; workshop to learn about } \\
\text { caring for donkeys; visits to } \\
\text { traditional houses to observe their } \\
\text { architecture; learning about the } \\
\text { ecological role of the architecture } \\
\text { of dovecotes. }\end{array}$ \\
\hline Estival & $\begin{array}{l}2008 \\
\text { Annual } \\
1 \text { week }\end{array}$ & $\begin{array}{l}\text { Rural and } \\
\text { remote } \\
\text { Dedicated } \\
\text { farm/ } \\
\text { camping area }\end{array}$ & $\begin{array}{l}\text { Free entrance } \\
\text { for local } \\
\text { residents to } \\
\text { workshops and } \\
\text { free music and } \\
\text { food event in } \\
\text { the village on } \\
\text { one night }\end{array}$ & $\begin{array}{l}40+25 \text { artists } \\
+25 \\
\text { volunteers }\end{array}$ & $\begin{array}{l}\text { Workshops in: mosaic-making, } \\
\text { felting, wood sculpture, dance, } \\
\text { theatre, stand-up comedy, comic } \\
\text { book design, and singing. }\end{array}$ \\
\hline $\begin{array}{l}180 \text { Creative } \\
\text { Camp }\end{array}$ & $\begin{array}{l}2013 \\
\text { Annual } \\
8 \text { days }\end{array}$ & $\begin{array}{l}\text { Small city } \\
\text { In the } \\
\text { historical city } \\
\text { centre and in a } \\
\text { few outskirt } \\
\text { locations }\end{array}$ & $\begin{array}{l}\text { Free attendance } \\
\text { for local } \\
\text { residents to } \\
\text { night-time } \\
\text { music events }\end{array}$ & Up to 120 & $\begin{array}{l}\text { Every year there are } 4 \text { full-day } \\
\text { parallel workshops with invited } \\
\text { artists featuring, for example, } \\
\text { photography, drawing, } \\
\text { illustration, publishing, } \\
\text { animation, architecture, cardboard } \\
\text { mask-making. }\end{array}$ \\
\hline
\end{tabular}




\section{Results and Analysis}

Small-scale festival organizers' strategies to increase local community involvement within festivals involve both economic and non-economic dimensions. In addition to economic transactions with local residents to provide services and products necessary for the production of the festival, local residents (and often the visiting participants themselves) also engage in activities such as volunteering to help in the running of the festival as well as practices of mutual aid in the form of cooperating with artists to create artistic performances. Small-scale local festivals also act as development frameworks for creative tourism activities. The integration of creative tourism activities, which are defined as experiences that include elements of active participation, creative self-expression, connection to place, and community engagement (Bakas, Duxbury, and Castro, 2018), can increase the social utility of festivals. The ways in which festival organizers perceive creative tourism activities to be creating social utility are now thematically analyzed.

\subsection{Small-scale festivals as fertile ground for the evolution of creative tourism activities}

Festival contexts have long been associated with opportunities for experimentation and 'trying something new', which can provide a fertile setting for developing and evolving creative tourism activities. Hands-on experiences in the form of creative activities are something that festival participants often demand; as the Estival organizer says: "Initially the workshops were for performative arts, but people started to say that they wanted to be creative with their hands. This was something I added to the program" (Estival, site visit interview, 2017). In festivals that include a number of creative workshops, the act of engaging in these creative practices tends to neutralize the working environment, encouraging people to experiment with new ideas and helping them express themselves more freely -- the EncontrArte organizer says that the festival creates a "different atmosphere" that encourages experimentation and free expression (EncontrArte site-visit interview, 2017). Many of the festival organizers say that their festivals create 'socially safe' spaces for the participants to experiment with activities that they might not try outside this environment. For example, the organizer of Estival observes that "people feel very safe to be and to participate here - it is physically and socially safe!" (Estival, sitevisit interview, 2018). In Miranda do Douro, the itinerant festival engenders social closeness and a lot of participation, especially evident in the collaboration required for the daily tasks of the Festival (i.e., transportation, organization, food, and general logistics), which translates into a very 'familiar' environment (L Burro i L Gueiteiro site-visit interview, 2018).

As well as creating a socially safe space, it is observed that there is something about the informal and continuous mixing of artists and other participants that is special about smallscale art festivals, which makes these events a fertile ground for the development and evolution of creative tourism activities. This informal mixing can mean that creative workshops sometimes 'evolve' organically. For example, in Estival, a mosaic-making workshop evolved on a daily basis in conjunction with an artist's work to finish covering a sculpture with mosaic. Another workshop emerged with the same artist who, after finishing the mosaic sculpture, started making a huge wooden sculpture, which festival participants voluntarily helped to make. As is recorded in fieldnotes from the 2018 Estival festival, "this same artist was making a massive wooden sculpture (called a 'kiss to the earth'), and many people helped her make it - paint it, sand it, stick it together - this was an innovative workshop that just evolved and was beautiful" (fieldnotes, 9 August 2018, Estival). 


\subsection{Social utility of integrating creative tourism activities within small-scale festivals}

Past research has shown that engaging in common activities in a context such a workshop can enhance social networks and strengthen the social fabric of a community by enabling meaningful social interaction among people without imposing social boundaries (Lam et al., 2018). Perceiving an event as a "symbolic social space" (Ziakas, 2016, p. 1140), where participants and audiences internalize shared meaning through projected event symbolisms, this section investigates how these shared meanings facilitate a heightened sense of community and strengthen a community's social capital. Festival organizers in this study define the local community as comprising local residents both from the village where the festival takes place and from neighbouring villages, local associations, local musicians, and children (fieldnotes from 2018 Estival, 180 Creative Camp, and L Burro i L Gueiteiro; and EncontrArte 2017). In this study, the term 'community' is used to reference the festival's "portable community" (Laing and Mair, 2015, p. 252), which includes all persons involved in the festival in some way, that is, the local community as described by the festival organizers and also paying (visiting) participants. The analysis presented in this section focuses on the ways in which festival organizers perceive the community and how social capital is generated within their festival in order to reveal instances when the festivals' social utility is made visible.

\subsubsection{Bridging, bonding, and linking}

Elements of social capital, such as trust and cooperation can be nurtured through the participation in cultural activities, such as creative tourism activities in festivals. In the four small-scale art festivals examined, it has been observed that the creative tourism activities incorporated within the event facilitate interaction between various groups of people that do not usually mix, including artists, local residents, children, and elderly people. This mixing of volunteers, artists, participants, and local residents who have a wide spectrum of backgrounds and interests can facilitate interaction across social strata, ethnic backgrounds, and gender and age divides, increasing social capital for all involved. At EncontrArte, for example, it is specifically the mixing of artists and other participants that increases the festival's social utility; as the organizers note, "EncontrArte creates a different atmosphere, it has artists wandering around, working directly with the local population..." (EncontrArte site-visit interview, 2017). The Estival organizer also stresses that the mixing of artists and other participants during the festival is what creates a special atmosphere; as she says, "The ambience at the festival was very friendly and arty - which was facilitated by the mixture of artists and participant on a daily basis and at various instances - during the workshops, during meals, during evening shows. This proximity was something that both participants and artists enjoyed" (Estival, sitevisit interview, 2018). This 'enjoyment' talks to the bridging social capital that is being generated as bonds between people who are dissimilar are created through these interactions.

The creative tourism workshops within the small-scale festivals are particularly good at catalyzing the mixing of people from various age-groups; as the Estival organizer says, "Young and old people mix really well in the workshops and that is great! They are helping each other in the workshops. This is very interesting as they try to create a community there. Everyone is valued and respecting" (Estival, site-visit interview, 2018). Similarly, in the L Burro i L Gueiteiro festival, the significance of interaction between various age groups is stressed; as the organizers observe: "The interaction amongst the participants is something that distinguishes this festival from others because it is a very friendly festival. It is friendly because we are able to involve both kids and adults in our activities, that is, we work with age groups from the baby 
of months to people of 70, 80, 90 years" (L Burro i L Gueiteiro, site-visit interview, 2018). According to all the festival organizers, inter-generational mixing is a significant element in the strategic planning of their festivals. In this instance we see how bridging and perhaps linking social capital are being produced (if one perceives older persons as persons of authority), which is stimulated by their active participation in creative tourism activities within the festival context.

\subsubsection{Small is social}

It is observed that the smallness of scale contributes to feelings of safeness, as participants who are joined by common interest to participate in the festival are able to get to know each other over the duration of the event. As the Estival organizer says, "Being small is also a strength as people really get to know each other" (Estival, site-visit interview, 2017). 'Getting to know each other' means that people within the community are forming bonds amongst each other and illustrates an instance of how small-scale festivals can generate social capital by facilitating the formation of networks and increasing social cohesion (Rao, 2001). Small-scale events create tighter social networks and increase the connectedness of the local population more than mega-events do (Taks, Chalip, and Green, 2015).

One of the particularities that the smallness of the festivals promotes is the feeling of being part of a community and helping to contribute to a common good. When local residents get involved as volunteers in the event, this contributes to quality of life and increased community spirit and pride (Gibson, Kaplanidou, and Kang, 2012), but what happens when the paying festival-goers turn into impromptu volunteers? The L Burro i L Gueiteiro festival organizer says: "Participants even offer their help voluntarily to complete the daily tasks of the festival and it is this interaction, in fact, that later translates into a very friendly and 'familiar' ambiance"" (L Burro i L Gueiteiro, site-visit interview, 2018). This is an example of how participants strive to build trust by volunteering, which is a way in which social capital can be built (Rao, 2001). Participants in this example are encouraged by the festival ambiance to move beyond individualism, engaging instead in social activities of shared meanings. This action promotes the feeling of justice and cooperation among all, which leads to what the L Burro i L Gueiteiro festival organizer expresses as a "a very friendly and 'familiar' ambiance." An additional explanation for this behavior may be that small-scale festivals promote connectivity among diverse elements, such as the festival volunteers, locals, festival tourists, and artists, increasing these persons' collective social capital, which is an incentive (Brennan-Horley, Connell, and Gisbon, 2007).

\subsubsection{Pride of place - Local residents as art participants}

Particularly in rural areas, community members may view the festival not as a money-making tourist attraction but as an enjoyable community-based event that boosts community pride and where they participate as either host or visitor, or both (De Bres and Davis, 2001). In the smallscale arts festivals in this study, festival organizers say that an important aspect is that the local community also becomes part of artistic performances. This creative integration may incorporate aspects of their lives, thoughts, and realities as the core content of the artistic productions.

For example, at EncontrArte, an artist integrated everyday local practices into an artistic performance by recording life at a cafeteria as an input into the work. The EncontrArte organizer recounts this mixing of an artist with local residents via the festival, saying that in this specific case, "a Russian artist worked with art and community. We set a challenge for her to work and follow the whole process of the cafeteria. So, what was created was a participation 
and a co-creation, where the ladies shared their daily life ... and also brought a presentation, on the last day of the festival, ... about who they are and what they do" (EncontrArte site-visit interview, 2017). This is an example of where shared meaning is created among cafeteria workers and the festival's portable community, an act which increases the festival's social utility as a heightened sense of community is facilitated. This is an example of how a smallscale art festival provides an occasion when the community reifies their group identity, signalling their commitment to the common good (Rao, 2001). Building on the success of this initiative, in the 2019 edition of the festival, a resident artist ballerina will create a ballet featuring the cafeteria workers, according to the EncontrArte organizer (email communication, 27 May 2019).

Direct involvement of local residents as part of an artistic performance was also practiced within 180 Creative Camp; as the organizer says, "The project of the ' 100 faces' was a project of the Camp that was to meet the population. It chose known or not so known people and the idea was to create a collaborative dynamic recorded within a documentary film that involves community, regardless of age. It's fantastic to see the video in which the old men in the city are singing and dancing. This is extraordinary" (180 Creative Camp site-visit interview, 2018). This project is one way in which the festival encourages social leverage, increasing community spirit and pride, and promoting interactions within the layers of a host community's social fabric (De Bres and Davis, 2001). Furthermore, creating a documentary film that is seen by many outside the local community increases the social utility of the festival by boosting the local community's pride of place (Waterman, 1998).

\subsubsection{Building trust}

It is not always easy to engage the larger host communities as not all local residents are keen to participate in the activities offered, raising the issue of the extent to which local residents view these festivals as 'their own' and a part of their community's activities or as 'outside' at a physical and psychological distance. As the Estival organizer says, "We invited five villages, but only Faia came to the festa. [For the others,] 15 kilometres is too far, it is a psychological distance" in this rural and mountainous area (Estival, site visit interview, 2018). The 180 Creative Camp organizer also points out that it is sometimes hard to get the local community engaged as they are 'distrustful' of the festival as something that is for them. As he says, gaining local residents' trust is a long journey, but one that can gradually bring returns: "distrust in the first year, and in the second perhaps, but from the third year, we managed to gain a good relationship with the community. And they feel the emptiness the following week (after the festival ends)" (180 Creative Camp site-visit interview, 2018). This statement illustrates how festivals may eventually have a social utility function by facilitating the formation of networks and increasing social cohesion, but first need to reinforce ties to and within the local resident community and build trust among these residents in order to be successful.

After trust has been gained and local networks established, local residents welcome small-scale festivals to take part in their village. For example, the L Burro i L Gueiteiro festival that has been running for the last 14 years has gained the trust of local residents, who relish the festival visiting their village. As the festival organizer says, "it is very pleasing to them that the festival passes through their villages... and local communities themselves ask the festival to pass back through their villages" (L Burro i L Gueiteiro, site-visit interview, 2018). These observations and reflections indicate that planning for events with social utility requires careful and longterm communications, relationship-building, and shared trust. It also points to the longer-term desirability of discussing ideas about event planning and programming, and the involvement 
of the local community members meaningfully in the planning and delivery of the festivals, not only in terms of audience reception.

\section{Conclusion}

This research shows that small-scale festivals can break down boundaries and create a liminal 'safe space' for the duration of the festival that allows for experimentation through creative tourism activities such as participatory creation workshops and installations. Viewing festivals conceptually as spaces of cultural practice and community celebration, the results suggest that the spaces generated by festivals prompt participants to partake in more co-creative cultural and community-based activities than they would outside the festival space, thus contributing to the successful insertion of creative tourism products into the festivals. Simultaneously, active participation in creative tourism activities, characterized by a sense of closeness and camaraderie among participants and transcending age, race, and gender barriers increases bonding opportunities among the festival participants, thus increasing the festivals' social utility.

Contextual dynamics facilitate or inhibit the creation of shared meaning and social capital within an event. Strategically planning to increase the moments where the festival community can create social capital can be achieved in various ways. One way is through enhancing the opportunities for festival community members to interact with other groups of people that do not usually mix, including artists, local residents, children, and elderly residents. Mixing volunteers, artists, participants, and local residents who have a wide spectrum of backgrounds increases bridging and linking social capital in this setting. Offering opportunities for persons of all ages to work together and bond is also important for the festival community's enjoyment. As the L Burro i L Gueiteiro festival organizer says, one factor that "distinguishes this festival from others" is that they "work with age groups from the baby of months to people of 70,80 , 90 years." Integrating creative tourism workshops within small-scale festivals provides festival organizers a way to increase the social utility of festivals as these activities are particularly good at catalyzing the mixing of people from various age-groups; as the Estival organizer says, "Young and old people mix really well in the workshops and that is great! They are helping each other in the workshops. This is very interesting as they try to create a community there" (Estival site-visit interview, 2018).

We find that the festival community internalizes shared meaning through projected event symbolisms, and these shared meanings facilitate a heightened sense of community and strengthen a community's social capital. When a Russian artist involved cafeteria workers in a show about "their daily [lives], ... about who they are and what they do" that was presented to the festival's community, it became an enjoyable activity for the whole community as an instance of shared meaning creation (EncontrArte site-visit interview, 2017). The festival community had met the cafeteria workers throughout the festival and this presentation gave the workers' perspective. These small-scale art festivals can also increase a community's pride of place. For example, the creation of a documentary of ' 100 faces' in 180 Creative Camp, was perceived as extraordinary by the festival organizers who say: "It's fantastic to see the video in which the old men in the city are singing and dancing. This is extraordinary" (180 Creative Camp site-visit interview, 2018). Presentation of local place-related characteristics in this way can also combat the 'McRuralisation' (Figueiredo, 2013) of rural tourism.

The scale of festivals is also important in terms of building social capital. In the situation where paying participants voluntarily help, it is the festival's ambiance that encourages them to move 
beyond individualism. This action promotes the feeling of justice and cooperation among all, which leads to what the L Burro i L Gueiteiro festival organizer expresses as a "very friendly and 'familiar' ambiance." As having a positive ambiance is a priority for festival organizers, creating moments where participants are encouraged to move beyond individualism and engage in social activities of shared meaning can be key.

We find that small-scale art festivals need to reinforce ties within the local community and build trust among local residents in order to be successful. This process is built on and nurtured through careful and long-term communications, relationship-building, and shared trust between local community residents and the festival organizers, as well as the behaviors and relationships in which visiting artists and other festival participants engage with one another and with local residents in respectful manners. Over time, the dynamics and activities brought forward through these small-scale festivals have a positive psychological value for the local communities, encouraging them to see their everyday spaces 'with a different eye', highlighting appreciation and intrinsic values of local natural assets and cultural traditions, and leading to a 'virtuous cycle' by which local residents look forward to the festivals visiting and residing in their villages/small towns into the future.

The limitations of this study, which focuses on the perspectives and insights of the festival organizers and site-visit observations, must be acknowledged. An analysis of the creative tourists' (participants) views, local community stakeholder analysis, and community impact analyses would offer further insights into small-scale festivals as a development framework for creative tourism and the ways in which community engagement is fostered and achieved. These are research items being investigated as part of the ongoing investigation within CREATOUR. Since willingness to return to events is influenced by the creation of communitas within a festival (Jahn et al., 2018), other future research might usefully examine the festival communities' perceptions of communitas created within such small-scale art festivals with a creative tourism component, and question if this ultimately influenced their choice of on-site activities and workshops and their intentions to return in future years.

The future of the rural is a critical issue and this research offers some suggestions of ways in which organizers of small-scale festivals can contribute to the social and cultural fabric of sustainable development of rural communities and small cities. Small-scale art festivals can provide platforms for interactive, creative experiences with local residents, and act as points for creating positive and meaningful images and understandings of rural realities. The inclusion of creative tourism activities as an integral component of these small-scale rural festivals can provide focal points for extended interaction among visiting and resident participants. Consequently, these organized occasions can have a strategic and profound effect on making the world - and travel experiences within it - more meaningful and connected.

\section{Acknowledgements}

This article results from a research project on creative tourism in small cities and rural areas, entitled CREATOUR: 'Creative Tourism Destination Development in Small Cities and Rural Areas' (Project 016437), supported by the Joint Activities Programme of Portugal 2020, by Compete 2020, POR Lisboa, POR Algarve and the Foundation for Science and Technology (FCT). The authors would like to thank the individuals involved in the interviews for their time and valuable insights and also the researchers Juliana Alves, Ricardo Gôja, and Tiago Vinagre de Castro for their contributions to this article. 


\section{References}

Agha, N. and Taks, M. (2015), "A theoretical comparison of the economic impact of large and small events", International Journal of Sport Finance, Vol. 10 No. 3, pp. 199-216.

Akhoondnejad, A. (2016), "Tourist loyalty to a local cultural event: The case of Turkmen handicrafts festival", Tourism Management, Vol. 52, pp. 468-477. doi: 10.1016/J.TOURMAN.2015.06.027

Anderson, S. and Ray, P. (2015), "Cultural creative and emerging planetary wisdom culture", available at: http://culturalcreatives.org/cultural-creatives/ (accessed 21 February 2018).

Bakas, F.E. and Duxbury, N. (2018), "Development of rural areas and small cities through creative tourism: The CREATOUR project", Anais Brasileiros de Estudos Turísticos (ABET), Vol. 8 No. 3, pp. 74-84.

Bakas, F.E., Duxbury, N. and Castro, T.V. (2018), "Creative tourism: catalysing artisan entrepreneur networks in rural Portugal”, International Journal of Entrepreneurial Behavior and Research, Vol 25 No. 4, pp. 731-752. https://doi.org/10.1108/IJEBR-032018-0177

Bell, D. and Jayne, M. (2010), "The creative countryside: Policy and practice in the UK rural cultural economy", Journal of Rural Studies, Vol. 26 No. 3, pp. 209-218. https://doi.org/https://doi.org/10.1016/j.jrurstud.2010.01.001

Blapp, M. (2015), Creative Tourism in Bali's Rural Communities Examination of the Current Offer and Advice on Future Product Development. PhD thesis, NHTV Breda University of Applied Sciences.

Brennan-Horley, C., Connell, J. and Gisbon, C. (2007), "The Parkes Elvis Revival Festival: Economic development and contested place identities in rural Australia", Geographical Research, Vol. 45 No. 1, pp. 71-84. doi: 10.1111/j.1745-5871.2007.00429.x.

Brito, M.P. and Richards, G. (2017), "Guest editorial [of special issue on 'Events and placemaking']”, International Journal of Event and Festival Management, Vol. 8 No. 1, pp. 2-7. https://doi.org/10.1108/IJEFM-01-2017-0007

Chalip, L. (2006), "Toward social leverage of sports events"”, Journal of Sport and Tourism, Vol. 11 No. 2, pp. 109-127.

Chen, L.I.-L., Scott, N. and Benckendorff, P. (2017), "Mindful tourist experiences: A Buddhist perspective", Annals of Tourism Research, Vol. 64, pp. 1-12. https://doi.org/https://doi.org/10.1016/j.annals.2017.01.013

Coleman, J.S. (1988), "Social capital in the creation of human capital", American Journal of Sociology, Vol. 94 (Supplement), pp. S95-S120.

Comunian, R. (2015), "Festivals as communities of practice: Learning by doing and knowledge networks amongst artists", in Newbold, C., Jordan, J., Bianchini, F. and Maughan, C. (Eds.), Focus on Festivals: Contemporary European Case Studies and Perspectives, Goodfellow Publishers, Oxford, pp. 53-65.

CREATOUR (2017), "Overview of CREATOUR", available at: http://creatour.pt/en/about/overview/ (accessed February 1, 2018).

Currie, J. (2005), "The mindful traveler: A guide to journaling and transformative travel", Nova Religio: The Journal of Alternative and Emergent Religions, Vol. 8 No. 3, pp. 123-125. https://doi.org/10.1525/nr.2005.8.3.123

da Silva, D.S., Figueiredo, E., Eusébio, C. and Carneiro, M.J. (2016), "The countryside is worth a thousand words: Portuguese representations on rural areas", Journal of Rural Studies, Vol. 44, pp. 77-88.

De Bres, K. and Davis, J. (2001), "Celebrating group and place identity: A case study of a new regional festival”, Tourism Geographies, Vol. 3 No. 3, pp. 326-337. doi: $10.1080 / 14616680110055439$. 
Derrett, R. (2003), "Making sense of how festivals demonstrate a community's sense of place", Event Management, Vol. 8 No. 1, pp. 49-58.

Duxbury, N., Campbell, H. and Keurvorst, E. (2011), "Developing and revitalizing rural communities through arts and culture", Small Cities Imprint, Vol. 3 No. 1, pp. 111-122.

Duxbury, N., Carvalho, C., Castro, T.V. de, Bakas, F.E. and Silva, S. (2018), "Packaging creative tourism offers in small cities and rural areas: A national overview of emerging models", presentation at "Emerging and Future Trends in Creative Tourism" international conference, 7-9 June 2018, Braga, Portugal.

Duxbury, N. and Richards, G. (2019), "Towards a research agenda for creative tourism: developments, diversity, and dynamics", in Duxbury, N. and Richards, G. (Eds.), $A$ Research Agenda for Creative Tourism, Edward Elgar Publishing, Cheltenham, UK, pp. $1-14$.

Duxbury, N., Silva, S. and Castro, T.V. (2019), "Creative tourism development in small cities and rural areas in Portugal: insights from start-up activities", in Jelinčić, D.A. and Mansfeld, Y. (Eds.), Creating and Managing Experiences in Cultural Tourism, World Scientific Publishing, Singapore.

Felsenstein, D. and Fleischer, A. (2003), "Local festivals and tourism promotion: The role of public assistance and visitor expenditure", Journal of Travel Research, Vol. 41 No. 4, pp. 385-392.

Ferreira, I. and Duxbury, N. (2017). "Cultural projects, public participation, and small city sustainability”, in Asikainen, S., Brites, C., Plebańczyk, K., Rogač Mijatović, L. and Soini, K. (Eds.), Culture in Sustainability: Towards a Transdisciplinary Approach, SoPhi, University of Jyväskylä, Department of Social Sciences and Philosophy, Jyväskylä, Finland, pp. 46-61, available at: http://urn.fi/URN:ISBN:978-951-39-7267-7 (accessed 12 June 2019).

Figueiredo, E. (2013), "McRural, no rural or what rural? - Some reflections on rural reconfiguration processes based on the promotion of Schist Villages Network, Portugal", in Silva, L. and Figueiredo, E. (Eds.), Shaping Rural Areas in Europe: Perceptions and Outcomes on the Present and the Future (GeoJournal Library, vol 107), Springer, Dordre, pp. 129-146.

Georgievska-Jakovleva, L. and Pavlovski, M. (2015), "Strumica, the city I want to live in!", in Hristova, S., Dragićević Šešić, M. and Duxbury, N. (Eds.), Culture and Sustainability in European Cities: Imagining Europolis, Routledge, London, pp. 219-230.

Gibson, C. and Connell, J. (Eds.) (2011), Festival Places: Revitalizing Rural Australia, Channel View Publications, Bristol.

Gibson, H.J., Kaplanidou, K. and Kang, S.J. (2012), "Small-scale event sport tourism: A case study in sustainable tourism”, Sport Management Review, Vol. 15 No. 2, pp. 160-170. doi: https://doi.org/10.1016/j.smr.2011.08.013.

Gibson, C. and Connell, J. (2016), Music Festivals and Regional Development in Australia, Routledge, London.

Glover, T.D. and Hemingway, J.L. (2005), "Locating leisure in the social capital literature" , Journal of Leisure Research, Vol. 37 No. 4, pp. 387-401.

Grappi, S. and Montanari, F. (2011), "The role of social identification and hedonism in affecting tourist re-patronizing behaviours: The case of an Italian festival", Tourism Management, Vol. 32 No. 5, pp. 1128-1140. https://doi.org/10.1016/j.tourman.2010.10.001

Jahn, S., Cornwell, T.B., Drengner, J. and Gaus, H. (2018), “Temporary communitas and willingness to return to events", Journal of Business Research, Vol. 92, pp. 329-338. https://doi.org/https://doi.org/10.1016/j.jbusres.2018.08.005

Jepson, A. and Clarke, A. (2013), "Community festivals and community development: 
Inclusive or exclusive events", Research Themes in Events, CABI, Wallingford, Chapter 2.

Johnson, V., Currie, G. and Stanley, J. (2011), "Exploring transport to arts and cultural activities as a facilitator of social inclusion", Transport Policy, Vol. 18 No. 1, pp. 68-75. https://doi.org/https://doi.org/10.1016/j.tranpol.2010.06.001

Kitterlin, M. and Yoo, M. (2014), "Festival motivation and loyalty factors", Tourism and Management Studies, Vol. 10 No. 1, pp. 119-126.

Kostopoulou, S., Vagionis, N. and Kourkouridis, D. (2013), "Cultural festivals and regional economic development: Perceptions of key interest groups", in Matias, Á., Nijkamp, P. and Sarmento, M. (Eds.), Quantitative Methods in Tourism Economics, PhysicaVerlag: Springer, Berlin, pp. 175-194.

Laing, J. and Mair, J. (2015), "Music festivals and social inclusion - the festival organizers' perspective", Leisure Sciences, Vol. 37 No. 3, pp. 252-268.

https://doi.org/10.1080/01490400.2014.991009

Lam, B., Phillips, M., Kelemen, M., Zamenopoulos, T., Moffat, S. and de Sousa, S. (2018), "Design and creative methods as a practice of liminality in community-academic research projects", The Design Journal, Vol. 21 No. 4, pp. 1-20. https://doi.org/10.1080/14606925.2018.1469329

Landry, C. (2010), "Experiencing imagination: Travel as a creative trigger", in Wurzburger, R., Aageson, T., Pattakos, A. and Pratt, S. (Eds.), A Global Conversation. How to Provide Unique Creative Experiences for Travelers Worldwide, Sunstone Press, Santa Fe, pp. 33-42.

Lau, Y. (2016), “Analyzing festival tourism: Effects on place, people and identity”, $H K U$ Theses Online (HKUTO), available at: http://hub.hku.hk/handle/10722/239637 (accessed 13 June 2019).

Lee, J. (Jiyeon) (2014), "Visitors' emotional responses to the festival environment", Journal of Travel and Tourism Marketing, Vol. 31 No. 1, pp. 114-131. doi:

10.1080/10548408.2014.861726.

Liepins, R. (2000), 'New energies for an old idea: Reworking approaches to 'community' in contemporary rural studies", Journal of Rural Studies, Vol. 16 No. 1, pp. 23-35. https://doi.org/https://doi.org/10.1016/S0743-0167(99)00042-X

Lincoln, Y.S. and Guba, E.G. (1985), Naturalistic Inquiry, Sage, Beverly Hills, CA.

Mair, J. and Whitford, M. (2013), "An exploration of events research: event topics, themes and emerging trends", International Journal of Event and Festival Management, Vol. 4 No. 1, pp. 6-30. https://doi.org/10.1108/17582951311307485

Matarasso, F. (2004), Arts in Rural England: Why the Arts are at the Heart of Rural Life, Arts Council England, London, available at: http://webarchive.nationalarchives.gov.uk/20160204123524/http://www.artscouncil.org. uk/advice-and-guidance/browse-advice-and-guidance/arts-in-rural-england-why-thearts-are-at-the-heart-of-rural-life (accessed 13 June 2019).

McKercher, B. and du Cros, H. (2002), Cultural Tourism, Haworth, New York.

Narayan, D. and Pritchett, L. (1999), "Cents and sociability: Household income and social capital in rural Tanzania", Economic Development and Cultural Change, Vol. 47 No. 4 , pp. 871-897.

Newbold, C., Maughan, C., Jordan, J. and Bianchini, F. (Eds.) (2015), Focus on Festivals: Contemporary European Case Studies and Perspectives, Goodfellow Publishers, Oxford.

O’Sullivan, D. and Jackson, M.J. (2002), "Festival tourism: A contributor to sustainable local economic development?", Journal of Sustainable Tourism, Vol. 10 No. 4, pp. 325-342.

OECD. (2014), OECD Tourism Trends and Policies 2014, OECD Publishing, Paris, available 
at: http://dx.doi.org/10.1787/tour-2014-en (accessed 13 June 2019).

Ortiz, J. (2017), Culture, Creativity and the Arts: Building Resilience in Northern Ontario.

$\mathrm{PhD}$ thesis, University of the West of England.

Picard, D. and Robinson, M. (2006), "Remaking worlds: Festivals, tourism and change", in Picard, D. and Robinson, M. (Eds.), Festivals, Tourism and Social Change: Remaking Worlds, Channel View Publications, Clevedon, pp. 1-31.

Rao, V. (2001), "Celebrations as social investments: Festival expenditures, unit price variation and social status in rural India", The Journal of Development Studies, Vol. 38 No. 1, pp. 71-97. doi: 10.1080/713601102.

Reid, S. (2007), "Identifying social consequences of rural events", Event Management, Vol. 11 No. 1-2, pp. 89-98.

Remoaldo, P.C., Matos, O., Freitas, I., Lopes, H., Ribeiro, V., Gôja, R. and Pereira, M. (2019), "Good and not-so-good practices in creative tourism networks and platforms: An international review", in Duxbury, N. and Richards, G. (Eds.), A Research Agenda for Creative Tourism, Edward Elgar Publishing, London, UK, pp. 167-181.

Richards, G. (Ed.) (2007), Cultural Tourism: Global and Local Perspectives, Haworth, New York.

Stankova, M. and Vassenska, I. (2015), "Raising cultural awareness of local traditions through festival tourism", Tourism and Management Studies, Vol. 11 No. 1, pp. 120127.

Stevenson, N. (2016), "Local festivals, social capital and sustainable destination development: Experiences in East London", Journal of Sustainable Tourism, Vol. 24 No. 7, pp. 990-1006.

Taks, M., Chalip, L. and Green, B.C. (2015), "Impacts and strategic outcomes from nonmega sport events for local communities", European Sport Management Quarterly, Vol. 15 No. 1, pp. 1-6. doi: 10.1080/16184742.2014.995116.

UNESCO. (2015), Festival Statistics: Key Concepts and Current Practices, UNESCO, Montreal.

UNTWO. (2016), Global Report on the Transformative Power of Tourism: A Paradigm Shift Towards a More Responsible Traveller, UNTWO and the Institute for Tourism (Zagreb), Madrid, available at: http://cf.cdn.unwto.org/sites/all/files/pdf/global_report transformative power tourism v5.compressed 2.pdf (accessed 13 June 2019).

Veltri, F., Miller, J. and Harris, A. (2009), "Club sport national tournament: Economic impact of a small event on a mid-size community", Recreational Sports Journal, Vol. 33 No. 2, pp. 119-128.

Verinis, P.J. (2011), "New immigrants and neo-rural values: The small non-Greek farmers of global Greek countrysides", Anthropological Journal of European Cultures, Vol. 20 No. 1, pp. 48-68.

Vidal, A.C. (2004), "Building social capital to promote community equity", Journal of the American Planning Association, Vol. 70 No. 2, pp. 164-168.

Walmsey, D.J. (2003), "Rural tourism: A case of lifestyle-led opportunities", Australian Geographer, Vol. 34 No. 1, pp. 61-72.

Waterman, S. (1998), "Carnivals for elites? The cultural politics of arts festivals", Progress in Human Geography, Vol. 22 No. 1, pp. 54-74. doi: 10.1191/030913298672233886.

Yolal, M., Gursoy, D., Uysal, M., Kim, H.L. and Karacaoğlu, S. (2016), "Impacts of festivals and events on residents' well-being", Annals of Tourism Research, Vol. 61, pp. 1-18.

Ziakas, V. (2016), "Fostering the social utility of events: an integrative framework for the strategic use of events in community development", Current Issues in Tourism, Vol. 19 No. 11, pp. 1136-1157. https://doi.org/10.1080/13683500.2013.849664 
Ziakas, V. and Costa, C.A. (2012), "'The show must go on': Event dramaturgy as consolidation of community", Journal of Policy Research in Tourism, Leisure and Events, Vol. 4 No. 1, pp. 28-47. doi: 10.1080/19407963.2011.573392. 